\title{
The Determinant of Firm Investment: The Case of Listed Jordanian Industrial Companies
}

\author{
Ghassan Omet ${ }^{1}$, Hadeel Yaseen ${ }^{2} \&$ Tareq Abukhadijeh ${ }^{1}$ \\ ${ }^{1}$ Faculty of Business, Department of Finance, University of Jordan, Jordan \\ ${ }^{2}$ Banking and Finance Department, Applied Science Private University, Jordan \\ Correspondence: Hadeel Yaseen, Banking and Finance Department, Applied Science Private University, Amman \\ (11931), P. O. Box 166, Jordan. E-mail: h_yassin@asu.edu.jo
}

Received: June 3, 2015

Accepted: June 20, 2015

Online Published: August 22, 2015

doi:10.5539/ijbm.v10n9p53

URL: http://dx.doi.org/10.5539/ijbm.v10n9p53

\begin{abstract}
Relative to the recent performance of the Jordanian economy, it can be argued that the private sector must be encouraged to increase investment levels. Indeed, the central idea behind the establishment of the Jordanian capital market in 1978 was to promote savings by activating and encouraging investment in bonds and shares and to direct such savings to serve the development of the national economy.

The fact that firm investment is an important indicator of the health of economies, this study investigates the investment behavior of listed Jordanian industrial firms during the period 2000-2013. Based on the financial statement of 52 listed industrial firms and panel data analysis, the empirical results indicate that firm investment does respond to stock market valuation (Tobin's Q). On the other hand, firm's leverage does not have a significant effects on firm investment. Based on these outcomes, one can argue that the pricing efficiency of the listed firms' stock is extremely important.
\end{abstract}

Keywords: Amman securities exchange, firm-level capital investment, Tobin's Q, leverage, liquidity

\section{Introduction}

Economists, as well as others, have always been interested in what really determines economic growth and development. As expected, this interest has led to the formulation of a number of theoretical models and numerous empirical papers.

Based on various methodologies, the empirical literature has examined the role of a myriad of factors including "financial development" (the establishment and expansion of institutions, instruments and markets). Based on this literature, one can argue that, on average, financial development does promote economic growth, industry growth, and firm growth (Levine, 2004; Demirguc-Kunt \& Levine, 2008).

As far as stock market are concerned, it is so remarkable to note that in about the last decade, stock exchange markets had opened in some of the least likely countries from Azerbaijan to Zambia. This might be to a certain extent due to an leading body of theoretical and empirical literature which has recognized a positive relationship between the status of financial development and the growth of economy (Minier, 2009). Indeed, at the theoretical level, two arguments raise the importance of stock markets.

The first argument (level effect) is due to Levine (1991). When the liquidity of listed securities improves, stock markets raise the accessibility of funds to finance long term capital investments. This is due to the fact that traders are assured of getting their buy and order executed "immediately" on the secondary market.

The second argument which is about the efficiency effects is due to Grenwood and Jovanovic (1990). It is argued that liquid stock markets improve investors' diversification benefits and this guides to a swing in their portfolios from low risk and low return investments to higher risk (high-return) investments. Naturally, this capital shift increases savings and investments and improves their allocated efficiency.

The fact that stock markets can be economically beneficial, many developing countries have established capital markets. For example, in Jordan, the Amman Securities Exchange (ASE) was found back in 1978.

As one might expect, the ASE started with some modest statistics. For example, in 1978, the market had a sum of 66 listed firms and with a market capitalization to Gross Domestic Product (GDP) equal to about 35 percent. 
Since 1978, however, the ASE has grown in a number of aspects. For example, by the end of 2014, the market capitalization to GDP has growth to 75 percent. Similarly, the number of listed firms is equal to 236 . It is also interesting to note that more than $40 \%$ of capitalization of the market is owned by non-Jordanians. Finally, the market boasts some of the largest (in terms of assets and sales) firms which operate in the country.

Referring to the over brief introduction, the key point of this study is to observe the impact of the ASE on firm-level capital investments during the period 2000-2013. The rest of the study proceeds as follows. A short review of the literatures which examines the determinants of firm investment is first presented. This is followed by a discussion of the data and methodology and empirical results. Finally, the paper summarizes the main findings and presents some implications for future research.

\section{Determinants of Firm Growth: Literature Review}

The issue of firm's growth has been the focus of many theoretical and empirical research papers. Indeed, this is not really surprising. First, firm growth is one of the successful outcomes of entrepreneurial efforts (Delmar \& Wiklund, 2008). Second, firms that experience higher growth create more jobs (Moreno \& Casillas, 2008). Third, newly emerging firms that grow and replace older ones is important for economic survival. It is common knowledge that business or firm growth is a compound fact. It can be measured in various ways including organizational aspects, individual issues, and business environment dimensions.

The organizational aspects include firm strategies, firm-specific resources, organizational structure, and dynamic capabilities (Coad, 2007).

The individual issues include the entrepreneur's personality traits (extraversion, emotional stability, agreeableness, conscientiousness, and openness to experience), need for achievement, risk-taking propensity, locus of control, self-efficacy, and extraversion, growth motivation, individual competencies and personal background (Casser, 2007).

The business environment dimensions include factors like employment regulations, regulations of entry of firms, access to finance, strength of property rights, quality of infrastructure, overall openness in the management of public resources, and others (Coluzzi et al., 2009).

In addition to the above literature which examines the determinant of firm growth, the financial economic literatures also contain many articles that examined the determinant of firm's growth in terms of fixed investments. These papers include Aivazian et al. (2005), Yuuan and Motohashi (2008), Bokpin and Onnumah (2009), Wang et al. (2009), Xiao (2009), Brruckner (2010), Duchin et al. (2010), Piris (2010), also Umutlu (2010), Geng and N'Diaye (2012), Reilly (2015), and others.

In general, the above-mentioned studies examined the firm's level fixed investments on a number of explanatory variables including Tobin's (equity's market value plus debt's book value to total asset's book value), cash flows, sales revenues, leverage, and liquidity. In other words, it is hypothesized in these studies that investments spending respond positively to stock markets valuation (Tobin's q), cash flow, current ratio, leverage, and liquidity.

Examining the effect of stock market developments in China on firm level capital investments, for example, it is affirmed that the sign of the coefficients are all as predicted. Investments spending respond certainly and significantly to the stock markets valuation, Tobin's. Also, the coefficient of cash flow and the coefficient of current ratio are both positively and extremely significant. On the other hand, there is no significant impact and the debt-to-equity ratios does not observed to be a control in the investments decision making procedure (Xiao, 2009).

\section{The Data, Methodology and Empirical Results}

As stated in the introduction, the most important object of this research is to give responses to the following two issues:

(1) The trend in fixed investment by listed Jordanian industrial firms in 2000-2013.

The primary variable of this part of the research is to measure the following variable: $\mathrm{I}_{\mathrm{it}} / \mathrm{FA}_{\mathrm{i}, t-1}$ where net fixed investments (I) computed as the annual differentiation in total net fixed asset $(\mathrm{K})$ is normalize by the starting of year K.

(2) The determinants of fixed investment by listed Jordanian manufacturing firms in 2000-2013.

Based on the available evidence, the following model will be estimated:

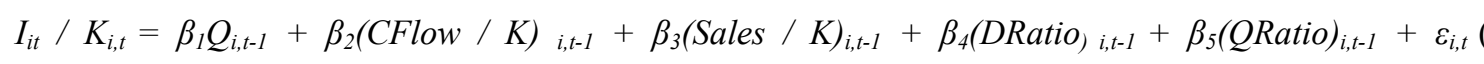


where the explanatory variable is the net fixed investments (I) (as defined above), Q is Tobin's q, CFlow represent cash flows, Sales set for sales revenues, DRatio is total liability to total asset ratio, QRatio is the current ratio (current assets minus inventory to current liabilities), $\varepsilon_{\mathrm{i}, \mathrm{t}}$ is the disturbance term, and $\mathrm{i}$ stands for company $\mathrm{i}(\mathrm{i}=1, \ldots .52)$ and $\mathrm{t}$ for the time period $(\mathrm{t}=2000-2013)$.

In other words, within the frame of the $\mathrm{q}$ assumption, the above-mentioned model states that firms investments is anticipated to react positively and high Tobin's Q ratio. In addition, and to account for any possible liquidity effects, cash flows are included in the model and is expected to positively affect investment.

The total number of listed industrial firms (52) accounts for about $75 \%$ of all listed industrial firms. In addition, these firms had all the necessary data for the econometric analysis. In other words, it can be argued that our sample of firms represent the listed industrial sector. In Table 1, we report the sectors to which these firms belong.

Table 1. Distributions of institutions based on industry

\begin{tabular}{ll}
\hline Industry & Number of Firms \\
\hline Mining \& Extraction & 10 \\
Chemical & 9 \\
Electrical & 4 \\
Engineering \& Construction & 5 \\
Food \& Beverage & 9 \\
Glass \& Ceramic & 1 \\
Paper \& Cartoon & 3 \\
Pharmaceutical \& Medical & 3 \\
Printing \& Packaging & 2 \\
Tobacco \& Cigarettes & 2 \\
Textile, Leather \& Clothing & 4 \\
Total & $\mathbf{5 2}$ \\
\hline
\end{tabular}

Source: ASE market 2015.

To account for the accelerator impact, sales revenues are then included and are anticipated to also have positive effects. Finally, to account for the influence of financial leverage and short-term liquidity, model (1) includes a measure of total liability to total asset and the quick ratio and these variables are expected to negatively and positively affect firm investment.

To examine the above panel regression model, three different methods are used; pooled ordinary least square, the fixed effect model, and the random effect model. However, the fact that the estimated value of the Hausman Chi Square statistic is equal to 21.662 , which is significant at the 99 percent confidence level, we report the fixed effects model.

It should be well-known that the benefit of using panel data which means combine inter-individual difference with intra-individual dynamic, over cross-sectional or time series data lie down in the truth that it y give a huge number of explanation and this increase the degree of freedom and for this reason, improve the efficiency of the econometric estimation. In addition, the benefit of using the panel data lies in the fact that it records for the unobserved heterogeneity among the cross-sectional companies over time in the type of unobserved firm-specific effect. Finally, as the samples include multi-year explanation, the correction techniques for unknown heteroskedasticity of White (1980) are used.

Table 2 shown descriptive statistics information for all variables. The most interesting variable is the net fixed investments $(\mathrm{I} / \mathrm{K})$. The standard deviation of net fixed investment to fixed assets $(0.324)$ is more than seven times its mean value and this suggests a high variation of investment among the sample of companies. 
Table 2. Descriptive statistics of regression variables

\begin{tabular}{llllll}
\hline Variables & Mean & Median & Maximum & Minimum & Std. Dev. \\
\hline I/K & 0.032 & 0.035 & 3.579 & -0.993 & 0.324 \\
Q & 1.393 & 1.083 & 11.919 & 0.318 & 1.055 \\
CFlow & 0.345 & 0.064 & 15.508 & -3.218 & 1.018 \\
Sales & 2.708 & 1.822 & 29.694 & 0.000 & 3.236 \\
DRatio & 0.325 & 0.297 & 0.945 & 0.004 & 0.210 \\
QRatio & 1.888 & 1.115 & 15.057 & 0.008 & 1.995 \\
\hline
\end{tabular}

Source: Estimated by authors.

It is worth noting that our sample of firms have relatively low leverage ratios. The overall mean value, which is equal to 32.5 percent, is much lower than, for example, the 56.7 percent in China (Li et al., 2009), 58.0 percent in Turkey (Tecker et al., 2009), 55.7 percent in Brazil (Bastos et al., 2009), 61.0 percent in Slovenia (Crnigoj \& Mramor, 2009), 60.0 percent in India, 61.3 percent in Pakistan, 56.4 percent in South Korea, 49.2 percent in Cyprus, 45.4 percent in Poland, 62.9 percent in Italy, 58.4 percent in Spain, 53.5 percent in Sweden, and the 52.8 percent in the U.K. (Muradoglu et al., 2010).

It is also interesting to note that the majority of the Jordanian companies do not have long-term debt on their records. Again, the almost zero percent long-term debt to assets ratio in Jordan is much lower than the 30.4 percent in Germany, 24.0 percent in Italy and the 17.0 percent in the UK (Muradoglu et al., 2010).

In Table 3, we report the mean annual values of net fixed investment (I/K). Again, based on the reported values, one can see that the years 2006 and 2008 witnessed the highest values. In addition, it is useful to note that the mean annual growth rate in net fixed investment was positive during the period 2002-2010. Naturally, this is due to the strong real economic growth witnessed during this period. For example, during the 2000-2004 and 2005-2009, the mean annual growth rates in real GDP were equal to 5.6 percent and 7.4 percent respectively.

Table 3. Firm investment: annual values

\begin{tabular}{llll}
\hline Year & I / K & Year & I/ K \\
\hline 2000 & -0.030 & 2007 & 0.023 \\
2001 & -0.049 & 2008 & 0.127 \\
2002 & 0.016 & 2009 & 0.029 \\
2003 & 0.036 & 2010 & 0.067 \\
2004 & 0.074 & 2011 & -0.005 \\
2005 & 0.035 & 2012 & -0.028 \\
2006 & 0.161 & 2013 & 0.016 \\
\hline
\end{tabular}

Source: Estimated by authors.

Table 4 reports the estimation result for the fixed effect model. Based on the reported results, a number of observations are made. These are outlined below:

First, on average, the signs and significance of the coefficients are as expected. For instance, the coefficients of Tobin's q (Q) is positive $(+0.032)$ and significant at the 99 percent confidence level. This observation implies that firms tend to invest more in fixed assets to exploit the growth options available to them.

Second, the coefficient of sales is significant and affect positively. This confirms the existence of the accelerator effect. The unexpected result is the insignificance of cash flow in impacting firm investment. This observation implies that firms do not rely on cash flow to finance their investments. Similarly, the negative coefficient of short-term liquidity (QRatio) signifies the fact that firms which are not liquidity-constrained tend to invest less. Indeed, the availability of internal funds means that firms are not financially constrained and hence do not need to pay a premium which is required on external financing. Finally, the financial leverage of firms does not affect their investment behavior. This result is probably expected given the fact the mean leverage ratio is relatively low. In other words, the existing leverage ratios do not prevent firms to invest if they choose to. 
Table 4. Determinants of investment: static model results

\begin{tabular}{lll}
\hline & Coefficients & Elasticity of Coefficients \\
\hline $\mathrm{Q}$ & $0.032^{* * *}$ & 1.393 \\
$(0.009)$ & \\
CFlow & -0.024 & -0.259 \\
& $(0.021)$ & \\
Sales & $0.061^{* * *}$ & 5.162 \\
& $(0.021)$ & \\
DRatio & 0.015 & 0.152 \\
& $(0.147)$ & \\
QRatio & $-0.032^{* * *}$ & -1.888 \\
& $(0.012)$ & --- \\
Observations & 728 & --- \\
No. of Firms & 52 & --- \\
Adjusted $\mathrm{R}^{2}$ & 0.145 & \\
\hline
\end{tabular}

Relative to the results which are reported in Table 3, it is useful to note that in term of the magnitudes of the coefficient, the elasticity of all coefficients at the mean are also reported in Table 3. For example, the elasticity of 1.393 indicates that a 10 percent increase in Tobin's $Q$ at the mean, will results in 13.93 percent growth in investment. This is calculated as follows: (the estimated coefficient of Tobin's Q * Mean of Tobin's Q) / Mean of the Dependent variable). Similarly, a 10 percent increase in the quick ratio will result in 18.88 percent decrease in investment. These results might be surprising. However, these large elasticities and increases in the resultant investment, are due to the fact the existing mean ratio of investment is low (3.2 percent).

The result which shows that stock market assessment (measured by Tobin's Q) has a significant determinant factor of firm investments has some serious implications. Indeed, it can be argued that if the ASE does not price its listed securities in an efficient manner (prices do not reflect economic fundamentals), the market might be allocating scarce economic resources in an inefficient manner. In other words, the stock markets might be encouraging (discouraging) investments which is not (is) useful. This argument must be taken seriously because the existing literature shows that the ASE is not efficient. This is why it is important to examine the pricing efficiency of the market and endure it is doing a good job in this aspect.

\section{A Summary and Conclusions}

Notwithstanding the significance of capital market in providing listed firms with long-term debt, and endorse the responsibility of the private sector in inspiring the economic growth, one can argue that all listed Jordanian companies must bear their fair share in enabling the Jordanian economy face its' daunting economic challenges. Based on this observation, this paper examines the role of the ASE in impacting firm-level investments. In other words, within the frame of Tobin's Q theory of investments, this paper examines the importance of stock markets valuation to investments decisions.

Using a data on a of 52 listed industrial companies during the period 2000-2013, the empirical results indicate that while the mean ratio of firm investment is low, firms directors in Jordan react positively and significantly to stock markets valuation while building investments decisions.

Based on the reported results, one can argue that the management of the ASE must take the pricing efficiency of the market seriously. If, for example, the prevailing stock prices do not reflect economic fundamentals, then the market might not be allocating scarce economic resources in an efficient manner. In other words, the stock market might be encouraging less productive firms to invest. In addition, based on the outcomes of this study, it is also worth examining the determinant of firm's growth in term of employment growth.

\section{References}

Aivazian, V., Ge, Y., \& Qiu, J. (2005). The impact of leverage on firm investment: Canadian evidence. Journal of Corporate Finance, 11, 277-291. http://dx.doi.org/10.1016/S0929-1199(03)00062-2

Bastos, D., Nakamura, W., \& Basso, L. (2009). Determinants of capital structure of publicly-traded companies in Latin America: The role of Institutional and macroeconomic factors. Journal of International Finance and Economics, 9, 24-39. 
Bokpin, G., \& Onumah, J. (2009). An empirical Analysis of the determinants of corporate investment decisions: Evidence from emerging market firms. International Research Journal of Finance and Economics, 33, 134-141.

Bruckner, M. (2010). Financial determinants of firm dynamics: Evidence from a European panel. Economics Letters, 107, 63-65. http://dx.doi.org/10.1016/j.econlet.2009.12.027

Casser, G. (2007). Money, money, money? A longitudinal investigation of entrepreneur career reasons, growth preferences and achieved growth. Entrepreneurship and Regional Development, 19, 89-107. http://dx.doi.org/10.1080/08985620601002246

Coad, A. (2007). Testing the principle of growth of the filter: The relationship between profits and firm growth. Structural Change and Economic Dynamics, 18, 370-386. http://dx.doi.org/10.1016/j.strueco.2007.05.001

Coluzzi, C., Ferrando, A., \& Martinez-Carrascal, C. (2009). Financing Obstacles and growth: An analysis for Euro area non-financial corporation. European Central Bank, Working Paper, No. 997. http://dx.doi.org/10.2139/ssrn.1333026

Crnigoj, M., \& Mramor, D. (2009). Determinants of capital structure in emerging European economies: Evidence from Slovenian firms. Emerging Markets Finance and Trade, 45, 72-89. http://dx.doi.org/10.2753/REE1540-496X450105

Delmar, F., \& Wiklund, J. (2008). The effect of small business managers' growth motivation on firm growth: A longitudinal study. Entrepreneurship: Theory and Practice, 32, 37-457. http://dx.doi.org/10.1111/j.1540-6520.2008.00235.x

Demirguc-Kunt, A., \& Levine, R. (2008). Finance, financial sector policies, and long-run growth. Commission on Growth and Development. Working Paper, No 11. http://dx.doi.org/10.1596/1813-9450-4469

Geng, N., \& N'Diaye, P. (2012). Determinants of corporate investment in China: Evidence from cross-country firm level data. IMF Working Paper, No., 12/80. http://dx.doi.org/10.5089/9781475502329.001

Greenwood, J., \& Jovanovic, B. (1990). Financial development, growth, and the distribution of income. Journal of Political Economy, 98, 1076-1107. http://dx.doi.org/10.1086/261720

Levine, R. (1991). Stock markets, growth, and tax policy. Journal of Finance, 46, 1445-1465. http://dx.doi.org/10.1111/j.1540-6261.1991.tb04625.x

Levine, R. (2004). Finance and growth: Theory and evidence. NBER Working Paper, No. 10766.

Minier, J. (2009). Opening a stock exchang. Journal of Development Economics, 90, 135-143. http://dx.doi.org/10.1016/j.jdeveco.2008.10.002

Moreno, A., \& Casillas, S. (2008). Entrepreneurial orientation and growth of SMEs: A causal model. Entrepreneurship Theory and Practice, 32, 507-528. http://dx.doi.org/10.1111/j.1540-6520.2008.00238.x

Muradoglu, G., Onay, C., \& Phylaktis, K. (2010). Capital structure and debt maturity in Europe: The role of FDI in European integration. Emerging Markets Group Working Paper Series No. 24, City University, London.

Piris, A. (2010). Investment by large firms in Argentina. IMF Working Paper, No. 3. http://dx.doi.org/10.5089/9781451961690.001

Reilly, C. (2015). Firm investment decisions in the post-conflict context. Economics of Transaition.

Umutlu, M. (2010). Firm leverage and investment decisions in an emerging market. Quality and Quantity, 44, 1005-1013. http://dx.doi.org/10.1007/s11135-009-9250-y

Wang, Y., Wu, L., \& Yang, Y. (2009). Does the stock market affect firm investment in China? A price $\mathrm{i}$ perspective. Journal of Banking and Finance, 33, 53-62. http://dx.doi.org/10.1016/j.jbankfin.2006.12.013

White, H. (1980). A Heteroskedasticity-consistent covariance matrix estimator and a direct test for heteroskedasticity. Econometrica, 48, 817-38. http://dx.doi.org/10.2307/1912934

Xiao, F. (2009). Does the stock market affect investment by Chinese firms? Some new evidence. International Review of Applied Economics, 23, 197-213. http://dx.doi.org/10.1080/02692170802700542

Yuan, Y., \& Motohashi, K. (2008). Impact of the debt ratio on firm investment: A case study of listed companies in China. RIETI Discussion Paper No. E-011, University of Tokyo.

Zhou, H., \& De Wit, G. (2009). Determinants and dimensions of firm growth. Scientific Analysis of Entrepreneurship and SMEs, Netherlands. 


\section{Copyrights}

Copyright for this article is retained by the author(s), with first publication rights granted to the journal.

This is an open-access article distributed under the terms and conditions of the Creative Commons Attribution license (http://creativecommons.org/licenses/by/3.0/). 